\title{
Deskripsi Sanitasi Lingkungan, Perilaku Ibu, dan Kesehatan Anak
}

\author{
Description of Environmental Sanitation, Maternal Behavior, and Child \\ Health
}

Kasnodihardjo, Elsa Elsi

\author{
Pusat Teknologi Intervensi Kesehatan Masyarakat Badan Penelitian dan Pengembangan Kesehatan Kementerian \\ Kesehatan Republik Indonesia
}

\begin{abstract}
Abstrak
Pada tahun 2009, dilakukan penelitian deskriptif di Kecamatan Jatibarang dan Kecamatan Kedokan Bunder untuk mengetahui faktor-faktor sanitasi lingkungan, dan perilaku ibu-ibu dan kejadian penyakit infeksi pada bayi dan anak. Data dikumpulkan menggunakan kuesioner dengan responden ibu rumah tangga yang mempunyai bayil anak balita berjumlah 401 orang. Penyakit diare pada bayi/anak disebabkan oleh media tercemar yang masuk ke sistem pencernaan melalui sumber air untuk minum maupun mandi, cuci, kakus (MCK) yang bukan berasal dari ledeng, keluarga yang tidak mempunyai jamban, ibu yang masih jarang mencuci tangan setelah membersihkan kotoran bayi ataupun setelah buang air besar, meminum dan memakan makanan yang tidak dimasak, dan sampah yang dibuang ke lingkungan. Penyakit Infeksi saluran pernapasan atas (ISPA), pneumonia, dan tuberkulosis paru pada bayi/anak kemungkinan disebabkan media tercemar masuk ke sistem pernapasan melalui sampah yang dibakar, membawa (menggendong) anak sewaktu memasak, merokok di dalam rumah berdekatan dengan bayilanak, menggunakan obat nyamuk bakar, penderita tuberkulosis paru meludah dan membuang dahak di sembarang tempat dan penderita tidur bersama anggota keluarga yang lain. Penyakit tular vektor pada bayi/anak (malaria) kemungkinan disebabkan upaya pencegahan gigitan nyamuk dengan repellent kurang efektif dan penggunaan kelambu masih rendah.
\end{abstract}

Kata kunci: Kesehatan bayilanak, perilaku ibu, sanitasi

\section{Abstract}

In 2009 a descriptive study conducted in the subdistrict Jatibarang and Kedokan Bunder to determine the factors of environmental sanitation, infectious disease in baby/child, and mother's behavior. Data were collected using questionnaires which respondents are 401 housewives who have a baby/child. Occurrence of diarrhea disease in baby/child because of the possibility of contaminated media through the digestive system by water for drinking and toilets which do not originate from the piping network, families who do not have own toilet, mothers who still seldom washing hands after cleaning the baby's stool or after a bowel movement, drinking and eating food that is not cooked and throw trash to the environment. Occurrence of respiratory diseases, pneumonia and pulmonary tuberculosis in baby/child possibly because the media is polluted through the respiratory system by burning garbage, carrying baby/children while, smoking at home or adjacent with babies/children, the use of mosquito coils, pulmonary tuberkulosis patients spit and throw phlegm in random places and sleeping with other family members. The occurrence of vector borne diseases in baby/child (malaria) because of the possibility of preventing mosquito bites with repellent less effective, the use of mosquito nets still low.

Keywords: Child health, mother behavior, sanitation

\section{Pendahuluan}

Lingkungan mempunyai andil yang paling besar terhadap status kesehatan yang disusul oleh perilaku. ${ }^{1}$ Kesehatan lingkungan adalah kondisi atau keadaan lingkungan optimum yang berpengaruh positif terhadap perwujudan status kesehatan optimum. Lingkup kesehatan lingkungan mencakup perumahan, pembuangan kotoran (tinja), penyediaan air bersih, pembuangan sampah, dan pembuangan limbah. ${ }^{1}$ Lingkungan berpengaruh sangat besar terhadap kesehatan manusia karena berbagai faktor penyebab penyakit dipengaruhi oleh lingkungan. Pengaruh lingkungan hidup terhadap kesehatan demikian penting sehingga penyebab penyakit sering harus dicari di luar tubuh yang berarti perlu penyelidikan lingkungan. Sanitasi lingkungan merupa-

Alamat Korespondensi: Kasnodihardjo, Pusat Teknologi Intervensi Kesehatan Masyarakat Balitbangkes Republik Indonesia, Jl. Percetakan Negara No.29, Jakarta Pusat, Hp.081311134648,e-mail: kasnodihardjo@litbang.go.id 
kan faktor penting yang harus diperhatikan, terutama sarana air bersih, ketersediaan jamban, pengolahan air limbah, pembuangan sampah, dan pencemaran tanah. Pembuangan tinja dapat secara langsung mengontaminasi makanan, minuman, sayuran, air tanah, serangga dan bagian-bagian tubuh. Perlu pengaturan pembuangan sampah agar tidak membahayakan kesehatan manusia karena dapat menjadi gudang makanan bagi vektor penyakit. Sayuran yang dimakan mentah dapat menjadi media transmisi penyakit dari tanah yang tercemar tinja. ${ }^{2}$

Perilaku manusia yang pada dasarnya adalah aktivitas manusia merupakan respons seseorang (organism) terhadap stimulus yang berhubungan dengan sakit dan penyakit. Perilaku tersebut meliputi peningkatan dan pemeliharaan kesehatan, pencegahan penyakit, pencarian pengobatan, sistem pelayanan kesehatan, makanan, serta lingkungan. Perilaku terhadap lingkungan kesehatan mencakup perilaku yang berhubungan dengan air bersih, pembuangan air kotor, limbah, rumah sehat dan pembersihan sarang nyamuk. Perilaku kesehatan merupakan berbagai hal yang berhubungan dengan tindakan atau kegiatan seseorang dalam memelihara dan meningkatkan kesehatan, termasuk juga tindakan untuk mencegah penyakit, kebersihan perorangan, memilih makanan, dan sanitasi. ${ }^{1}$

Kabupaten Indramayu merupakan salah satu wilayah di Provinsi Jawa Barat yang juga ikut berperan menyumbangkan kasus kematian bayi. Di Kabupaten Indramayu, periode Januari sampai September tahun 2008, kematian bayi sebanyak 417 kasus. Sebagian disebabkan oleh berbagai penyakit infeksi berbasis lingkungan, antara lain meliputi diare (17), infeksi saluran pernapasan atas (4), tetanus (8), bayi berat badan lahir rendah (BBLR) (74), asfiksia (57), dan infeksi (9). ${ }^{3}$ Faktor lingkungan terbukti berpengaruh terhadap angka kematian anak yang merupakan cermin kondisi kesehatan lingkungan. ${ }^{4}$ Penelitian ini bertujuan untuk mengetahui berbagai faktor sanitasi lingkungan, perilaku dan penyakit infeksi pada bayi/anak meliputi diare, infeksi saluran pernapasan atas, pneumonia, tuberkulosis paru, tetanus, demam berdarah dengue, malaria, dan demam tifoid.

Kejadian penyakit merupakan hasil hubungan interaktif antara manusia dengan perilaku dan lingkungan yang berpotensi penyakit. Agen penyakit adalah komponen lingkungan yang dapat menimbulkan gangguan penyakit melalui media perantara yang juga merupakan komponen lingkungan. Keberadaan suatu berbagai agen dalam media lazim dikenal dengan istilah pencemaran. Komponen lingkungan yang lazim dikenal sebagai media transmisi penyakit meliputi udara, air, tanah/pangan, binatang/serangga penular penyakit/vekor, dan manusia melalui kontak langsung. Jumlah kontak manusia dan komponen lingkungan yang berpotensi bahaya penyakit (agen penyakit) dapat diukur dalam konsep perilaku pe- majanan. Jumlah kontak pada setiap orang berbeda satu sama lain karena ditentukan oleh perilaku masingmasing. Jalan masuk atau route of entry dari agen penyakit ke dalam tubuh manusia meliputi sistem pernapasan, sistem pencernaan, dan permukaan kulit. ${ }^{5}$

Diare dan demam tifoid adalah penyakit infeksi sistem pencernaan yang merupakan dampak pencemaran air dan pangan oleh bakteri atau mikroba. ${ }^{6}$ Infeksi saluran pernafasan atas, pneumonia, dan tuberkulosis paru adalah penyakit infeksi pada sistem saluran pernapasan merupakan dampak pencemaran udara oleh bahan kimia, bakteri, atau mikroba. Penyakit demam berdarah dengue dan malaria adalah penyakit infeksi yang ditularkan melalui gigitan vektor nyamuk. Upaya paling efektif mencegah malaria adalah menghindari gigitan nyamuk Anopheles yang dapat dilakukan berupa proteksi pribadi dengan menggunakan insektisida (semprot atau dilapiskan pada kelambu) dan repellent. ${ }^{7}$ Pneumonia adalah salah satu penyakit infeksi saluran pernapasan akut dengan penyebab multifaktorial, diperkirakan terdapat efek faktor risiko individu dan faktor risiko tingkat ekologi. ${ }^{8}$ Tetanus adalah penyakit infeksi yang ditimbulkan oleh Clostridium tetani. Mikroorganisme ini ditemukan di tanah dan pada traktus intestinal, juga feses berbagai hewan. Tempat masuk mikroorganisme ini ke dalam tubuh adalah luka. ${ }^{9}$

\section{Metode}

Penelitian observasional ini tentang perilaku berisiko yang berhubungan dengan kejadian penyakit diare, infeksi saluran pernapasan atas, pneumonia, tuberkulosis paru, tetanus, demam berdarah dengue, malaria, dan demam tifoid. Desain penelitian yang digunakan adalah cross sectional. Populasi adalah ibu rumah tangga yang mempunyai bayi dan atau anak balita. Sampel adalah ibu rumah tangga yang mempunyai bayi dan atau anak balita yang memenuhi kriteria Penarikan sampel dilakukan secara acak dengan metoda simple random sampling. Besar sampel minimal setiap kelurahan dihitung menggunakan rumus Lemeshows atc. ${ }^{10}$

Dengan nilai perkiraan proporsi pengetahuan sikap dan perilaku (PSP) pada populasi $50 \%$, besar sampel yang didapatkan adalah 384,16 dan dibulatkan menjadi 400. Jumlah responden di kedua kecamatan lokasi penelitian adalah $400 \mathrm{ibu}$ yang mempunyai bayi dan atau anak balita, dengan sampel tiap kecamatan daerah adalah 200 responden. Data dikumpulkan melalui wawancara terstruktur dan pengamatan lapangan terhadap para objek yang diduga berhubungan erat dengan penularan diare, infeksi saluran pernapasan atas, pneumonia, tuberkulosis paru, tetanus, demam berdarah dengue, malaria, demam tifoid. Data diolah dan dianalisis secara deskriptif menggunakan paket program statistik dengan perangkat komputer. 
Kasnodihardjo \& Elsi, Deskripsi Sanitasi Lingkungan, Perilaku Ibu, dan Kesehatan Anak

Tabel 1.Proporsi Responden Menurut Kepemilikan Sarana Sanitasi

\begin{tabular}{llll}
\hline Sarana Sanitasi & Kategori & Jumlah & Persentase (\%) \\
\hline Sumber air MCK & Ledeng (PDAM) & 79 & 19,7 \\
& Sumur pompa & 132 & 32,9 \\
& Sumur gali & 183 & 45,6 \\
& Sungai & 7 & 1,7 \\
Sumber air minum & Air kemasan & 105 & 26,2 \\
& Ledeng (PDAM) & 180 & 44,9 \\
& Sumur pompa & 79 & 19,7 \\
& Sumur gali & 35 & 8,7 \\
& Membeli & 1 & 0,2 \\
Kepemilikan air bersih & Tidak terjawab & 1 & 0,2 \\
& Milik sendiri & 304 & 75,8 \\
Kepemilikan sarana MCK & Milik bersama/umum & 97 & 24,2 \\
& Milik sendiri & 325 & 81,0 \\
& Milik bersama/umum & 75 & 18,7 \\
Jumlah & Tidak terjawab & 1 & 0,3 \\
& & 401 & 100,0 \\
\hline
\end{tabular}

Keterangan :

MCK = Mandi cuci kakus

Tabel 2. Pola Pembuangan Sampah

\begin{tabular}{lll}
\hline Penangan Sampah & Jumlah & Persentase (\%) \\
\hline Diambil petugas & 41 & 10,2 \\
Dibuang di tong sampah & 3 & 0,7 \\
Dibakar & 241 & 60,1 \\
Dibuang di kebun & 59 & 14,7 \\
Dibuang ke sungai & 48 & 12,0 \\
Ditanam di lubang & 2 & 0,5 \\
Lainnya & 7 & 1,7 \\
Jumlah & 401 & 100,0 \\
\hline
\end{tabular}

\section{Hasil}

Proporsi responden yang memanfaatkan air minum dari Perusahaan Daerah Air Minum (PDAM) 44,9\%; air kemasan $26,2 \%$ dan sumur pompa $19,7 \%$. Umumnya responden mengambil air dari sumur gali $45,6 \%$; sumur pompa 32,9 \% dan dari ledeng (PDAM) 19,7. Masih ada responden yang menggunakan air sungai $(1,7 \%)$. Sarana air bersih $(75,8 \%)$ mandi, cuci, kakus (MCK) $(81,0 \%)$ lebih banyak dimiliki sendiri.

Pola penanganan sampah rumah tangga meliputi dimusnahkan dengan dibakar $(60,1 \%)$, dibuang di kebun $(14,7 \%)$, membuang di sungai $(12,0 \%)$, dan diambil petugas (10,2\%) (Tabel 2).

Berbagai penyakit infeksi yang pernah diderita oleh bayi dan/atau anak balita meliputi penyakit infeksi adalah diare $(25,2 \%)$, infeksi saluran pernapasan atas $(23,9 \%)$, pneumonia $(14,5 \%)$ dan tuberkulosis paru $(7,2 \%)$. Penyakit demam berdarah dengue $(0 \%)$, malaria $(2,7 \%)$, demam tifoid $4,5 \%$, dan tetanus $2,0 \%$ (Tabel $3)$.

Perilaku positif pencegahan penyakit diare dan demam tifoid adalah mencuci tangan dengan sabun
Tabel 3. Bayi atau Anak Balita yang Pernah Didiagnosis Penyakit Infeksi

\begin{tabular}{lcc}
\hline Jenis Penyakit & Jumlah & Persentase (\%) \\
\hline Diare & 101 & 25,2 \\
Infeksi Saluran Pernafasan Atas (ISPA) & 96 & 23,9 \\
Pneumonia & 58 & 14,5 \\
TB Paru & 29 & 7,2 \\
Tetanus & 8 & 2,0 \\
Demam Berdarah Dengue (DBD) & - & - \\
Malaria & 11 & 2,7 \\
Tifus & 18 & 4,5 \\
\hline
\end{tabular}

meliputi sebelum makan $(81,5 \%)$. Sesudah buang air $(61,8 \%)$ dan setelah membuang kotoran bayi $(54,1 \%)$. Sebagian besar responden (9,0\%) mempunyai jamban. Responden diasumsikan memanfaatkan jamban yang dimiliki. Perilaku positif memasak air sebelum diminum $(82,0 \%)$ dan mengonsumsi makanan matang $(19,0 \%)$. Perilaku mencegah penularan penyakit infeksi saluran pernapasan atas dan pneumonia meliputi tidak membawa bayi/balita memasak dapur $(57,6 \%)$, tidak merokok dekat bayi/balita $(46,1 \%)$, dan tidak merokok dalam rumah $(19,2 \%)$. Perilaku pencegahan penyakit tuberkulosis paru terbesar meliputi menutup hidung/mulut sewaktu bersin atau batuk $(74,8 \%)$, membuka jendela setiap hari $(72,3 \%)$ dan tidak membuang dahak atau meludah sembarangan $(35,7 \%)$. Proporsi perilaku yang terkecil adalah penderita tidak tidur bersama anggota keluarga lain $(1,7 \%)$. Perilaku pencegahan penyakit menular melalui vektor nyamuk terbanyak menggunakan repellent $(76,3 \%)$, obat nyamuk bakar $(35,9 \%)$ dan tidur berkelambu $(10,0 \%)$ dan terkecil adalah menggunakan obat semprot $(9,2 \%)$ (Tabel 4$)$.

\section{Pembahasan}

Sumber air minum berbeda dengan sumber air untuk mencuci dan MCK. Sebagian masyarakat menggunakan sumber air minum PDAM, di kabupaten Indramayu proporsi terbesar adalah sumur bor pompa. ${ }^{11}$ Sumber air untuk minum dan MCK masih banyak yang tidak menggunakan jaringan PDAM sehingga berisiko pencemaran dan mengalami penyakit infeksi saluran pencernaan. Masih ditemukan rumah tangga yang menggunakan sarana air bersih dan MCK secara bersama sehingga berisiko penularan penyakit infeksi. ${ }^{12}$

Metode pembuangan sampah terbanyak meliputi dibakar, dibuang di kebun, di sungai, di tong sampah dan ditanam di lubang sehingga dapat mencemari air, tanah, serta udara dan dapat menjadi tempat berkembang biak vektor penyakit dan mikroorganisme penyebab penyakit. 1,2

Penyakit infeksi berbasis lingkungan yang diteliti meliputi diare, infeksi saluran pernapasan atas, pneumonia, tuberkulosis paru, dan malaria, demam berdarah 
Tabel 4. Keterkaitan Perilaku dengan Penularan Penyakit Berbasis Lingkungan

\begin{tabular}{lll}
\hline Komponen Perilaku & Jumlah & Persentase (\%) \\
\hline Diare dan Tifus & & \\
Mencuci tangan dengan sabun sebelum makan & 327 & 81,5 \\
Mencuci tangan dengan sabun setelah BAB & 248 & 61,8 \\
Kepemilikan sarana BAB (milik sendiri dan bersama) & 348 & 99,0 \\
Mencuci tangan dengan sabun setelah membuang kotoran bayi & 217 & 54,1 \\
Minum air masak & 329 & 82,0 \\
Mengonsumsi makanan matang & 76 & 19,0 \\
& & \\
ISPA dan Pneumonia & & 57,6 \\
Tidak menyertakan bayi/balita waktu memasak di dapur & 231 & 46,1 \\
Tidak merokok dekat bayi/balita & 185 & 19,2 \\
Tidak merokok dalam rumah & 77 & 1,7 \\
TB Paru & & 35,7 \\
Tidak tidur bersama anggota keluarga lain & & 74,8 \\
Membuang dahak/meludah tidak sembarangan & 72,3 \\
Tutup hidung/mulut sewaktu bersin atau batuk & 7 & \\
Membuka jendela setiap hari & 143 & 300 \\
Penyakit Tular Nyamuk Vektor & 290 & 35,9 \\
Membakar obat nyamuk bakar & & 9,2 \\
Menggunakan obat semprot & & \\
Menggunakan repellent & 144 & 37 \\
Tidur menggunakan kelambu & 306 & \\
\hline
\end{tabular}

dengue, demam tifoid, tetanus. Penyakit dengan persentase terbesar adalah penyakit diare, diikuti dengan penyakit infeksi saluran pernapasan atas. Berbeda dengan Riset Kesehatan Dasar (Riskesdas) tahun 2007, di Kabupaten Indramayu, penyakit infeksi yang terbanyak adalah infeksi saluran pernapasan atas diikuti diare. ${ }^{11}$ Berdasarkan route of entry meliputi sistem pernapasan, sistem pencernaan, dan masuk melalui permukaan kulit. ${ }^{5}$ Proporsi penyakit infeksi terbesar adalah melalui sistem pernapasan $45,6 \%$, meliputi infeksi saluran pernapasan atas $(23,9 \%)$, pneumonia $(14,5 \%)$, dan tuberkulosis paru $(7,2 \%)$. Penyakit infeksi yang melalui sistem pencernaan $(29,7 \%)$, meliputi diare $(29,7 \%)$ dan demam tifoid $(4,5 \%)$. Penyakit infeksi yang melalui permukaan kulit $4,7 \%$, meliputi malaria $(2,7 \%)$, demam berdarah dengue $(0 \%)$, dan tetanus $(2,0 \%)$.

Untuk pencegahan penyakit diare dan demam tifoid, perilaku positif para ibu terbanyak adalah kepemilikan sarana buang air besar dan melakukan buang air besar di jamban. Namun, masih ada responden yang melakukan buang air besar tidak di jamban. Penelitian yang dilakukan di Jawa Barat menunjukkan bahwa jamban belum dirasakan sebagai kebutuhan mendesak karena ada alternatif lain di kebun atau di sungai. ${ }^{13}$ Pencucian tangan dengan sabun terbanyak dilakukan sebelum makan, sedangkan setelah buang air besar atau setelah pembuangan kotoran bayi jarang dilakukan. Perlakuan terhadap air minum yang dimasak sebelum diminum belum menyeluruh. Konsumsi makanan matang sangat kecil karena pola konsumsi makanan masyarakat Jawa Barat masih banyak memakan lalapan mentah yang dapat menjadi media pencemar penyakit infeksi. Pembuangan tinja dapat secara langsung mengontaminasi makanan, minuman, sayuran, air tanah, serangga (lalat, kecoa), dan bagian-bagian tubuh. ${ }^{2}$ Untuk pencegahan penularan penyakit infeksi saluran pernapasan atas dan pneumonia, terbanyak adalah tidak menyertakan bayi/balita waktu memasak didapur, tidak merokok dekat bayi/balita dan tidak merokok di dalam rumah tergolong rendah $(<50 \%)$. Balita perokok pasif dalam ruangan berisiko kesehatan serius dari perokok. ${ }^{14-16}$

Untuk pencegahan penyakit tuberkulosis paru perilaku yang terbanyak adalah menutup hidung/mulut sewaktu bersin atau batuk dan membuka jendela setiap hari. Sinar matahari yang langsung masuk ke dalam rumah berhubungan dengan penularan tuberkulosis paru. Balita yang tinggal serumah dengan orang dewasa penderita tuberkulosis paru dan rumah yang tidak dimasuki sinar matahari berisiko 3,5 kali lebih besar untuk tertular tuberkulosis paru dibandingkan yang tidak. ${ }^{17}$ Perilaku penderita tuberkulosis paru tidur tidak bersama anggota keluarga yang lain sangat jarang ditemukan.

Pencegahan dan penularan penyakit yang ditularkan vektor nyamuk terbesar adalah menggunakan repellent dengan bahan aktif Diethyltoluamide (DEET) yang 
merupakan pestisida beracun. Keampuhan produk repellent tergantung pada besar konsentrasi zat pengusir nyamuk, semakin tinggi konsentrasi, daya tahan sebagai obat pengusir nyamuk lebih lama. Penggunaan obat nyamuk jenis repellent perlu dioles berulang kali. ${ }^{18}$ Penggunaan repellent, obat nyamuk bakar, dan obat semprot tergolong tinggi yang dapat menyebabkan pencemaran udara. Perilaku tidur menggunakan kelambu masih tergolong rendah padahal kelambu tergolong ampuh mencegah gigitan nyamuk. ${ }^{12}$ Penggunaan kelambu berinsektisida yang dapat membunuh dan/atau menghalau nyamuk yang sederhana, mudah, efektif, dan murah. ${ }^{19}$

\section{Kesimpulan}

Belum semua warga memanfaatkan sumber air PDAM, pemenuhan kebutuhan air bersih terbanyak adalah sumur pompa dan sumur gali. Sarana air minum dan MCK masih ada yang milik bersama dan sampah masih sangat jarang yang diambil petugas. Penanganan sampah yang kurang baik menjadi sumber pencemar dan mengurangi keindahan lingkungan. Penyakit infeksi yang terjadi pada bayi/balita melalui sistem pernapasan lebih banyak daripada sistem pencernaan. Masih banyak ibu yang tidak mencuci tangan dengan sabun setelah buang air besar atau setelah pembuangan kotoran bayi, tidak memasak air sebelum diminum, memakan makanan yang tidak dimasak, menggendong bayi/balita ketika memasak di dapur, merokok dekat bayi/balita atau merokok di dalam rumah, tidur bersama penderita tuberkulosis dan membuang dahak atau meludah sembarangan. Mengusir nyamuk dengan repellent dapat mengakibatkan pencemaran udara, sementara perilaku positif ibu tidur menggunakan kelambu masih rendah. Sanitasi di kedua desa tergolong sangat rendah, penyakit infeksi pada bayi/anak terbanyak menular melalui saluran pernapasan. Namun, perilaku pencegahan penyakit infeksi melalui pencegahan pencemaran media transmisi penyakit masih kurang positif.

\section{Saran}

Peran ibu dalam keluarga yang masih mempunyai bayi dan atau anak balita merupakan modal pokok untuk mewujudkan dan meningkatkan keluarga sehat dan sejahtera. Mereka sangat berperan pada perkembangan dan kebersihan anggota keluarga. Setiap hari, ibu mengurus rumah tangga dan memelihara kebersihan dan kesehatan keluarga, berperan mengatur dan memberi contoh pada anggota keluarga tentang cara hidup yang bersih dan sehat. Perhatian seorang ibu yang kurang terhadap kebersihan rumah tangga dan anggota keluarganya dapat berakibat buruk bagi kesehatan. Keluarga dapat dijadikan basis dalam strategi intervensi menanggulangi masalah kesehatan bayi dan anak balita. ${ }^{20}$

\section{Ucapan Terima Kasih}

Ucapan terima kasih disampaikan kepada Pemerintah Daerah Kabupaten Indramayu, Fakultas Kesehatan Masyarakat Universitas Wira Lodra Kabupaten Indramayu yang memfasilitasi serta membantu tenaga dan sarana pelaksanaan penelitian ini serta Direktorat Jenderal Pendidikan Tinggi Kementerian Pendidikan Nasional Republik Indonesia yang mendanai penelitian ini.

\section{Daftar Pustaka}

1. Notoatmodjo S. Ilmu kesehatan masyarakat (prinsip-prinsip dasar). Jakarta: PT Rineka Cipta; 2003.

2. Sucipto AC. Aspek kesehatan masyarakat dalam AMDAL. Yogyakarta: Gosyen Published; 2011.

3. Dinas Kesehatan Kabupaten Indramayu. Profil kesehatan kabupaten Indramayu Provinsi Jawa Barat. Indramayu: Dinas Kesehatan Kabupaten Indramayu; 2008.

4. Supraptini, Afifah T. Kondisi kesehatan lingkungan di Indonesia dan angka kematian bayi, angka kematian anak balita serta angka kematian balita menurut data susenas 1998, 2001, dan 2003. Jurnal Ekologi Kesehatan. 2006; 5 (3): 512-5.

5. Achmadi UF. Manajemen penyakit berbasis wilayah. Depok: PT Rajagrafindo Persada; 2012.

6. Achmadi UF. Dasar-dasar penyakit berbasis lingkungan. Depok: PT Rajagrafindo Persada. 2012

7. Harijanto PN, Gunawan CA. Malaria: dari molekuler ke klinis. Jakarta: Penerbit Buku Kedokteran EGC; 2010.

8. Machmud R. Pneumonia balita di Indonesia dan peran kabupaten dalam menangulanginya. Padang: Andalas University Press; 2006.

9. Muliawan SY. Bakteri anaerob yang erat kaitannya dengan problem di klinik: diagnosis dan penatalaksanaan. Jakarta: Penerbit Buku Kedokteran EGC; 2009.

10. Lemeshow S. Adequacy of sample size in health studies. University of Massachusetts. Published on Behalf of the World Health Organization by John Wiley \& Sons; 1990.

11. Badan Penelitian dan Pengembangan Kesehatan Departemen Kesehatan Republik Indonesia. Laporan Hasil Riset Kesehatan Dasar (RISKESDAS) Provinsi Jawa Barat tahun 2007. Jakarta: CV Metro Nusa Prima; 2008.

12. Wolff CG, Schroeder DG, Young MW. Effect of improved housing on illness in children under 5 years old in northern Malawi: cross sectional study. British Medical Journal. 2001; 322: 1209.

13. Muzaham F. Studi tentang pola pembuangan kotoran di Provinsi Jawa Barat dan Sumatera Barat. Pusat Penelitian Ekologi Kesehatan; Badan Penelitian dan Pengembangan Kesehatan Departemen Kesehatan Republik Indonesia. 1981.

14. Soemarwoto O. Atur-diri-sendiri: paradigma baru pengelolaan lingkungan hidup. Yogyakarta: Gadjah Mada University Press; 2004.

15. Jung JW, Ju YS, Kang HR. Association between parental smoking behavior and children's respiratory morbidity: 5-year study in an urban city of South Korea Pediatric Pulmonology. 2012; 47 (4): 338-45.

16. Pramudiyani NA, Prameswari GN. Hubungan antara sanitasi rumah dan perilaku dengan kejadian pneumonia balita Jurnal Kesehatan. Jurnal Kesehatan Masyarakat. 2011; 6 (2): 71-8 
Kesmas, Jurnal Kesehatan Masyarakat Nasional Vol. 7, No. 9, April 2013

17. Musadad A. Hubungan faktor lingkungan rumah dengan penularan tuberkulosis paru kontak serumah. Jurnal Ekologi Kesehatan. 2006; 5 (3).

18. Anonim. Bahaya diethyltoluamide (DEET). Diunduh dari: insect - repellent. ik.pom.go.id/wp content/uploads/2011/bahaya DEET pada insect.pdf.

19. Harminarti N.Kelambu celup permetrin. Repository Universitas
Andalas. Majalah Kedokteran Andalas. 2008; 32 (1): 1-7.

20. Davis J, Pickering AJ, Rogers K, Mamuya S, Boehm AB. The effects of informational interventions on household water management, hygiene behaviors, stored drinking water quality, and hand contamination in peri Urban Tanzania. The American Journal of Tropical Medicine and Hygiene. 2011; 84 (2): 184-91 